\title{
EVALUATION OF EXTRACTION FORCE FOR WOODEN GUY ANCHORS
}

\section{by E. Thomas Smiley', Elden LeBrun², and Elizabeth Gilbert ${ }^{3}$}

\begin{abstract}
Wooden stakes are used to anchor guy lines on many newly transplanted trees. It has been recommended that the angle of the stake be either in-line with the guy ( 45 degrees toward the tree) or at right angles to the guy ( 45 degrees from horizontal away from the tree). This trial was conducted to determine which, if either, of these directions will provide the maximum amount of resistance to extraction. Stakes were driven into the soil at two angles and vertically into the soil then were extracted using a measured force. There was no significant difference in force required to extract the stakes driven in-line with the guy or at a right angle to it. There was a significant difference $(\mathrm{p}<.05)$ between angled stakes and those driven straight into the soil. The force required for extraction of the stake driven vertically was more than twice that of the angle-driven stakes. It was hypothesized that the differences in extraction force were due to soil disruption that occurs when driving stakes into the soil. For maximum strength, it is recommended that wooden stakes be driven vertically into the soil.
\end{abstract}

Key Words. Windthrow; staking; transplanting; guying.

Large transplanted trees that are prone to root failure due to wind or vandalism are often guyed for support for a year or more following transplanting. Guying is also used to support "righted" trees after they fail from wind or other reasons. Anchors that fasten guys need to stay in the ground during all normally encountered wind conditions and resist other forces that act on the tree. Pull-out failures have been observed during thunderstorms (Figure 1).

One of the most common guy systems is a wire or rope looped around the trunk and run to a wooden stake anchor. Wooden stakes are much less expensive than steel stakes or patented steel anchors. They also have the advantage of easier extraction than steel anchors or are biodegradable if left in the soil. Improving the wooden stake anchor system can allow the use of less expensive materials to achieve the same results as more expensive materials.

Wooden stakes should be driven into the ground at an angle that provides the greatest resistance to extraction so that pull-out is less likely to occur. However, there is no published research on the strongest angle for driving tree stakes. Two stake angles have been commonly recommended for use with trees: driving the stake at an angle of 90 degrees to the guy (equal to about 45 degrees from horizontal, away from the tree) (Harris et al. 1998) and inline with the guy (about 45 degrees from horizontal, toward the tree) (Watson and Himelick 1997).
From the anchor, the guy is run to the tree trunk. The recommended angle for the guy is typically 45 degrees from horizontal, but the guy is often installed at a steeper angle of 55 or 60 degrees (Watson and Himelick 1997; Harris et al. 1998).

This trial was conducted to determine which, if either, of these directions provides better resistance to wooden stake extraction. Since it is difficult to simulate the dynamic action of trees responding to wind, a steady force was used that more closely simulates the constant pull that vandals might exert on tree trunks.

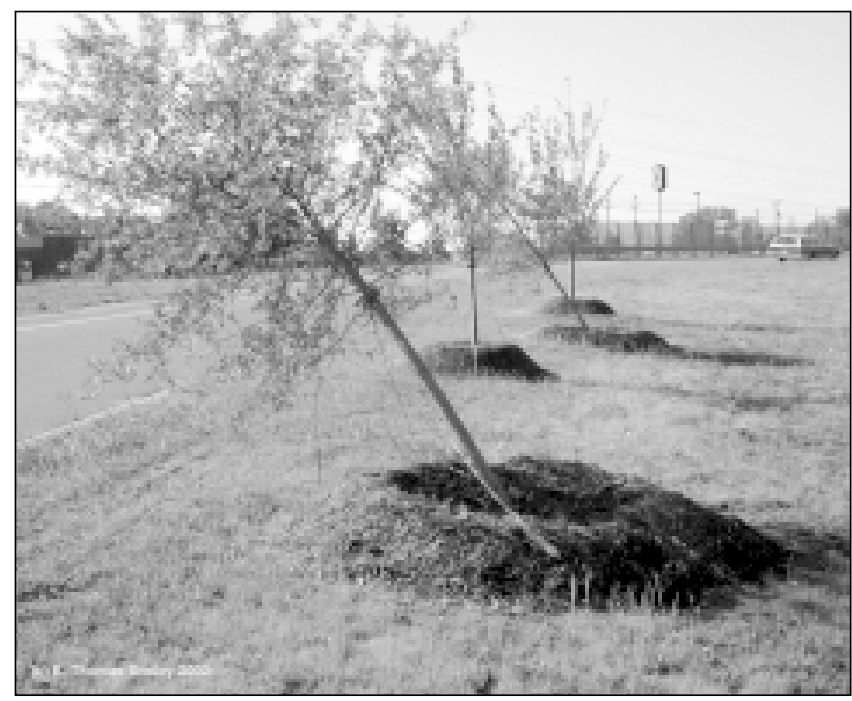

Figure 1. Wooden stakes were pulled out of the soil as a result of thunderstorm winds on these willow oaks (Quercus phellos) in Charlotte, North Carolina, U.S.

\section{MATERIALS AND METHODS}

Wooden stakes, 3.5 by 2.2 by $40 \mathrm{~cm}$ long were driven into the soil so that approximately $10 \mathrm{~cm}$ remained above the soil surface. Soil in the test area was a sandy clay loam soil (Cecil B) with a moisture level of $6.2 \%$ and soil bulk density of $1.6 \mathrm{mg} / \mathrm{m}^{3}$. Stakes were spaced far enough apart so that soil disruption from pulling one stake out of the soil would not affect any other stakes.

Stakes were driven at one of three angles: 45 degrees toward the tree, 45 degrees away from the tree, or vertically (90 degrees) into the soil (Figure 2). The number of stakes tested at each angle were 40,30 , and 40 , respectively. 


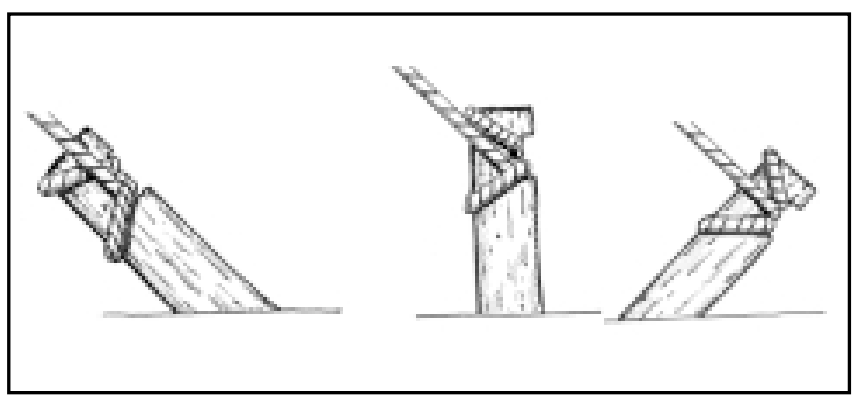

Figure 2. Stakes were driven at three angles-45 degrees toward the tree, straight into the soil, or 45 degrees away from the tree.

Stakes were extracted the same day that they were driven into the soil.

A Dillon 1,800 kg peak recording mechanical dynamometer (Weight-Tronix, Inc., Fairmont, MN) and block was attached to a large tree at a height that would provide an angle of pull or either 45 or 55 degrees from horizontal. A line was run from the stake through the block to a truckmounted winch. Stakes were pulled until they came out of the soil. Peak dynamometer readings were divided by two to determine the force required for extraction. Fifty stakes were pulled at a cable angle of 55 degrees, and 60 were pulled at an angle of 45 degrees.

Mean force required for extraction was statistically compared using an Analysis of Variance and the StudentNewman-Keuls separation of means.

\section{RESULTS}

Fracturing of the soil was noticed above the stakes driven either 45 degrees toward the tree or 45 degrees away from the tree. No soil disruption was noticed when stakes were driven vertically into the soil.

Mean extraction forces (measured in newtons, and showing standard deviations) for a cable pull angle of 45 degrees were 961 N, s.d. 405 (216 lb, s.d. 91); 1,157 N, s.d. 378 (260 lb; s.d. 85); and 2,390 N, s.d. 903 (537 lb; s.d. 203) for stake angles of 45 degrees toward the tree, 45 degrees away from the tree, and vertical, respectively (Figure 3).

For a cable pull angle of 55 degrees, mean extraction forces were $886 \mathrm{~N}$, s.d. 307 (199 lb, s.d. 69); 899 N, s.d. 347 (202 lb, s.d. 78); and 2,078 N, s.d. 1,558 (467 lb, s.d. 350), respectively.

Combined mean extraction force for stakes driven either 45 degrees toward the tree or 45 degrees away from the tree was slightly over $890 \mathrm{~N}$ (200 lb); for vertically driven stakes, it was approximately $2,225 \mathrm{~N}(500 \mathrm{lb})$. There was no significant difference in force required to extract the stakes driven at either 45 degree angle. There was a significant difference $(\mathrm{p}<.05)$ between both 45 angles and the stakes driven straight into the soil. There were no significant differences based on angle of pull regardless of stake angle.

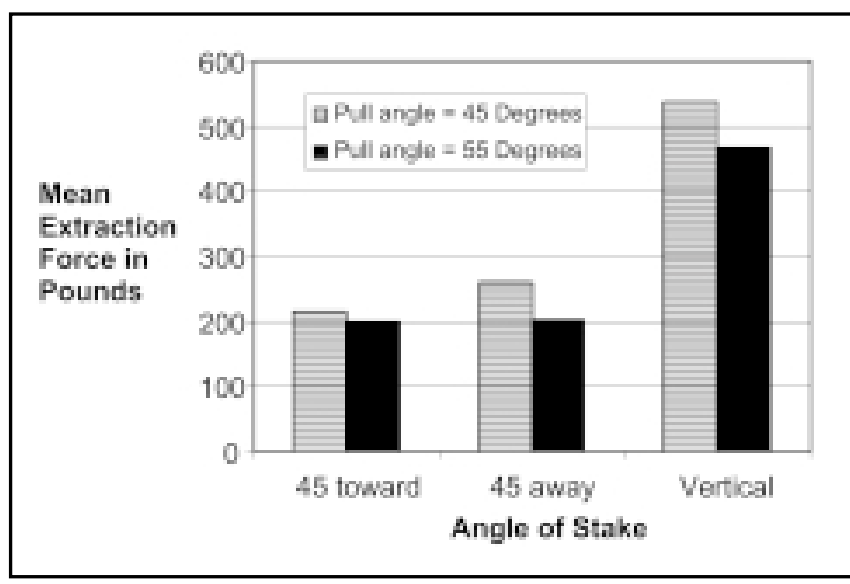

Figure 3. Force required to extract wooden stakes driven at one of three angles (45 degrees toward the tree, 45 degrees away from the tree, or straight into the soil) and pulled at an angle or either 45 or 55 degrees from horizontal, from a sandy clay loam soil $(1 \mathrm{lb}=4.45 \mathrm{~N})$.

\section{DISCUSSION}

The mean force required for extraction of the stake driven vertically was more than twice that of the angle-driven stakes. This fact is most likely due to the disruption of the soil structure that occurs when driving the stakes. When stakes are driven at an angle, they tend to lift and fracture the soil. The disturbed soil has less holding power than nondisturbed or compacted soil. When stakes are driven vertically into the soil, less soil disruption was observed. The soil surrounding vertically driven stakes is most likely compacted in the directions away from the stake.

When staking trees, it is desirable for the guy system to have the maximum possible strength with the materials used in order to resist tree failure under high wind conditions or with vandalism. This study found that the commonly recommended angles for driving wooden stakes into the soil have less resistance to extraction than a third option. This additional strength comes at no additional cost in materials or labor required to install the stakes.

A wind resistance study using 6.5 to $7.6 \mathrm{~cm}$ caliper ash (Fraxinus) trees exposed to a $22 \mathrm{~m} / \mathrm{s}(50 \mathrm{mph}$ ) wind had a wind load in excess of $890 \mathrm{~N}$ (200 lb) (Smiley et al. 2000). One tree in the study experienced a force of $890 \mathrm{~N}$ in an 18 $\mathrm{m} / \mathrm{s}$ (40 mph) wind. It was estimated that it would take a wind speed of $45 \mathrm{~m} / \mathrm{s}$ ( $45 \mathrm{mph}$ ) to exceed 1,623 N (365lb). Relating these numbers to this study, an angled stake would be able to support a typical 6.5 to $7.6 \mathrm{~cm}$ caliper ash to about $22 \mathrm{~m} / \mathrm{s}$, while a vertically driven stake would support the tree to in excess of $45 \mathrm{~m} / \mathrm{s}$. Thunderstorms often produce winds that exceed $22 \mathrm{~m} / \mathrm{s}$, but rarely do they exceed $45 \mathrm{~m} / \mathrm{s}$.

This study was conducted under dry soil conditions. With more soil moisture, soil disruptions caused by driving 
stakes in at an angle may be different. Additional testing of stake extraction forces in different soil textures and with different moisture conditions should be conducted to verify the results presented.

\section{LITERATURE CITED}

Harris, R.W., J.R. Clark, and N.P. Matheny. 1998.

Arboriculture: Integrated Management of Landscape Trees, Shrubs, and Vines. Prentice Hall, Upper Saddle River, NJ. 687 pp.

Smiley, E.T., A. Key, and C. Greco. 2000. Root barriers and windthrow potential. J. Arboric. 26(4):213-217.

Watson, G.W., and E.B. Himelick. 1997. Principles and Practice of Planting Trees and Shrubs. International Society of Arboriculture, Champaign IL. 200 pp.

Acknowledgments. We would like to thank Donnie Merritt for the drawings, Tom Martin and Kelly Marshall for manuscript review, and Bruce R. Fraedrich, Director of the Bartlett Tree Research Laboratories.

1"Arboriculture Researcher

Bartlett Tree Research Laboratory

13678 Hamilton Road

Charlotte, NC 28278, U.S.

and Adjunct Professor, Clemson University

${ }^{2}$ Research Technician

Bartlett Tree Research Laboratory

Charlotte, NC, U.S.

${ }^{3}$ Graduate Student

Myerscough College

Lancashire, UK

Résume. Des piquets de bois sont utilisés pour ancrer les câbles d'arbres nouvellement transplantés. Il a été recommandé que l'angle du piquet soit ou dans l'axe du câble (angle de $45^{\circ}$ vers l'arbre) ou encore à angle droit par rapport au câble (angle de $45^{\circ}$ par rapport à l'axe horizontal et orienté du côté opposé à l'arbre). Cette étude a été menée afin de déterminer laquelle de ces deux méthodes - ou encore les deux - allait procurer le maximum de force de retenue contre l'extraction des piquets. Les piquets ont été enfoncés dans le sol à deux angles différents ainsi que verticalement, et ont par la suite été arrachés au moyen d'une force mesurable et constante. Il n'y avait pas de différence significative dans la force requise pour extraire les piquets plantés dans l'axe du câble ou ceux plantés à angle droit par rapport au câble. Il y avait une différence significative $(\mathrm{p}<0,05)$ entre les piquets plantés en angle et ceux plantés directement dans le sol à la verticale. La force requise pour extraire un piquet planté verticalement était plus de deux fois supérieure à celle requise pour les piquets plantés en angle. Il a été émis comme hypothèse que les différences dans les forces d'extraction étaient dues à des perturbations du sol qui se produisent lorsque les piquets sont enfoncés dans le sol. Pour une force maximale, il est recommandé que les piquets de bois soit plantés verticalement dans le sol.

Zusammenfassung. An vielen neugepflanzten Bäumen wurden Holzpfähle als Anker für Richtschnüre gesetzt. Es wurde empfohlen, dass der Winkel für die Pfähle entweder in Reihe mit den Richtschnüren (45 Grad zu Baum) oder im rechten Winkel zur Richtschnur (45 Grad horizontal vom Baum weg) stehen soll. Dieser Versuch wurde durchgeführt, um zu bestimmen, welche von diesen Einrichtungen maximalen Schutz gegenüber Extraktionen bietet. Die Pfähle wurden mit zwei Winkeln und vertikal in den Boden getrieben und wurden dann mit einer gemessenen Kraft extrahiert. Es gab keine signifikanten Unterschiede in der Kraft bei den in Reihe oder im rechtem Winkel gesetzten Pfählen. Es gab signifikante Unterschiede $(\mathrm{p}<.05)$ zwischen gewinkelten und gerade eingetriebenen Pfählen. Die erforderliche Kraft zur Extraktion vertikal eingetriebener Pfähle war zweimal so groß wie bei den winkeligen Pfählen. Es wurde die Hypothese formuliert, dass die Differenzen bei der Extraktion durch bodenbedingte Schwierigkeiten, die bei der Einsetzung der Pfähle auftraten, entstanden. Für eine maximale Stärke wird empfohlen, dass die Pfähle vertikal gesetzt werden.

Resumen. Las estacas de madera son utilizadas para anclar los tensores en muchos árboles recién transplantados. Se ha recomendado que el ángulo de la estaca sea en línea con el alambre $\left(45^{\circ}\right.$ con el árbol) o en ángulo recto al alambre ( $45^{\circ}$ con la horizontal desde el árbol). Este ensayo se realizó para determinar cuál dirección proporcionará la máxima resistencia a la extracción. Las estacas fueron colocadas dentro del suelo en los dos ángulos y también verticalmente; luego fueron extraídas usando una fuerza que se registró. No hubo diferencia significativa en la fuerza requerida para extraer las estacas colocadas en línea con el alambre o en ángulo recto a él. Sí hubo una diferencia significativa $(\mathrm{p}<.05)$ entre las estacas anguladas y la colocada verticalmente en el suelo. La fuerza requerida para extraer la estaca colocada verticalmente fue más del doble que la de las anguladas. Se planteó la hipótesis de que esas diferencias en la fuerza de extracción se debieron a la roturación que ocurre en el suelo cuando se colocan las estacas. Para una máxima resistencia se recomienda que las estacas de madera se coloquen verticalmente dentro del suelo. 